\title{
INFLUENCE FACTORS AND MANIFESTATIONS OF PRODUCTIVITY
}

\author{
Daniel DĂNECI-PĂTRĂU, Assistant Professor PhD \\ Spiru Haret University of Bucharest \\ Faculty of Management Financial Accounting Constanta \\ Email: danusidenima2@yahoo.com \\ Elena Carmen COCA, Assistant Professor PhD Student \\ Tomis University Constanţa \\ Email: zelesneacarmen@yahoo.com
}

\begin{abstract}
Notion almost unknown before 1950, labor productivity is now commonly used by economists, engineers, sociologists and politicians alike, influencing all the important issues of the time. Under these circumstances, if it is accepted that labor productivity is the driving variable that generates economic progress, it is justified that people need to increase their efforts to enhance, its value through various means. This article presents the findings of a theoretical research literature regarding landmarks in the evolution of labor productivity. Arguments justifying such an approach have been given by the fact that the labor issue presents an interest not only at the micro level, individual (the consequences it has on the individual work), but also at the macro level, societal (employment relations on the market labor, insurance systems and the offer educational services on the market today).
\end{abstract}

Keywords: productivity, human capital, labour, labour productivity

JEL Classification: $\mathrm{D}_{21}, \mathrm{D}_{24}$

\section{Introduction}

Labour productivity can be viewed at the micro level within a company as being highlighted by reporting the obtained production at the labour factor used either at the level of national economy as a ratio between macro-indicator of gross domestic product or national income and employment (most relevantly expressed as the annual number of hours actually worked by employees).

The first question that we can think about is: Why study the work and labour productivity? Firstly, because labour activity occupies most of the time in one's active life.

In general, employees consider labour productivity and its actions a method of the employer to raise workload and employers see it as a method to reduce wages and thus, increasing profit. Work "contains an intrinsic value and expresses in a certain degree the essence of the human being: we are what we produce" (Giarini and Liedtke, 2001), the man in relationship with the society and to himself through the successes and/or failures of his activities. The manifestation of a 
national economic crisis, starting with the fourth semester of 2008, has generated a long line of anti-crisis measures, which have resulted in lower labour productivity, trend seen not only at national level but also in all European countries that have implemented stringent measures, namely, Lithuania and Greece [1].

According to research conducted by trade unionists and experts inside the field of labour market research, labour productivity in Romania is about half the European average, significantly lower than in Croatia, Macedonia and Turkey, countries outside the European Union. In order to balance the state budget, the government has deemed it appropriate to reduce public spendings by massive layoffs of public sector employees and reducing public wages by $25 \%$. These measures have generated chain effects in the private sector of activity as well, thus according to the National Employment Agency Employment Agency (NEA), unemployment rate has increased from $4.4 \%$ in 2008 to $7.8 \%$ in 2009 and then gradually decrease without reaching today the existing level in 2008, so wages diminished overall. According to research conducted by trade unionists and experts from the field of labour market research, labour productivity in Romania is about half the European average, significantly lower than in Croatia, Macedonia and Turkey, countries outside the European Union.

\section{Highlights in the evolution of labour productivity}

The largest contribution to labour productivity growth is brought by the investment in human capital. Human capital is the totality of an individual's professional knowledge and skills, he highlights the production capacity and reproduction of the economy, it develops over time and can have long-term effects, being subjected to impairment (Platis, 2000). Investing in human capital essentially refers to any activity designed to ensure an increase in the quality and capacity of the human factor capable of generating long-term future flows, added value and income.

The concept of human capital is mentioned since 1776 when, in his work "Wealth of Nations", Adam Smith considers that society wealth is the result of productive work and depends largely on the amount and ability of trained workforce that performs the work (Smith, 1992). Therefore, in the author's opinion, there is a separation of the capital invested in human and non-human. The cost of training is suitable according to smithiene belief, an investment in future earning capacity represented by wages and economic rent. With the advent of private form of capital and nature (earth), which contribute to increase productivity and production, the "value of labour" - according to the smithiene theory - does not appear fully in salary but is divided in the form of rent and thus profit [2], an idea later taken over by Karl Marx. As an economist of the manufacturing period when physical strength played an important role in achieving a certain level of labour productivity, Smith was the follower of wage increase only with the increase of production and wealth of the country; pay rises were not justified in stagnation or regression cases. Otherwise, pay rises would lead to a lower national wealth thus the fall in national economy resulting in lower wages. 
Under present conditions, when many operations that mostly require physical effort, are being taken over by technical capital, under its tangible or intangible form enhancing in exchange the creative side of the human factor, wage growth is conditioned by a multitude of other items such as: means of production performance, patented or unpatented licenses, know-how, investment in training and staff development and training and retraining it, market conditions, relationship between employer and trade union, inflation rate and cost of living.

Jean Baptiste Say, as a systematiser of the Adam Smith doctrine distinguishes between the developer and owner of capital, highlighting the important role of the first in the production and distribution of wealth (Say, 1803). Skilled entrepreneurs combine best utility services (which print value to goods) of factors: work, capital, nature. Through the market mechanism, the law of supply and demand factors regulate the prices of services, in the same way product prices are adjusted. In other words, according to JB Say's vision, labour is treated as any other commodity traded on an ideal market with pure and perfect competition, fact denied by the historical developments of the labour market. Instead, Say achieves a first anticipation of the current theory on human capital, when he appreciates that for a medical advice to be given and received, the doctor or his parents had to spend many years on training expenses - as well as in the case of a lawyer, musician, these costs representing an "accumulated capital".

Witness of the misery of most workers and unemployment, which rose significantly, JCL Simond of Sismondi, follower of utopian socialism rejects the liberal conception regarding the purpose of economic activity - increasing wealth, placing man at the centre of economic analysis and physical well-being: "If we consider wealth in itself, forgetting people, is the most certain way to get lost" (Gide and Rist, 1926). Sismondi's merit lies not only from illustrating some of the shortcomings of economic and social development of his time, but also that he meets their remedy through a series of measures to mitigate the social costs without threatening private property. Many of them find their echo in social legislation, noting as significant: granting the right of association for workers, public assistance workers unemployed and prohibition of child labour, limiting the working day.

Strategic place which workforce now occupies under the form of human capital requires a reconsideration of some economic theories on labour and the development of new theories that correspond to economic realities, an idea supported by a number of Romanian specialists who considers that the XXI century foreshadows the amplification of knowledge in all areas, promotes competition, stimulates initiative and creativity (Angelescu, 2000). The undisguised purpose of these actions is that each employee produces more goods in the same amount of time.

\section{Determinant factors of labour productivity}

Increasing labour productivity means reducing systematic manpower costs, reflected on the unit, work or service which directly contributes to lower costs and increase efficiency of work performed. Finally, labour productivity growth makes conditions growth in the volume of material production, GDP and accumulations, improving living standards and life of citizens. 
The main factors influencing the level of labour productivity are:

- Technical progress;

- Improving the organization of management, production and employment;

- Qualification, professional performers and increasing skills.

Appreciation of the importance of the human factor, of his major contribution on meeting the requirements of social life is directly linked to the extent of fully improving its potential functional capacity of work in productive activity.

Increasing the contribution of each economic agent of each labour team and general economic development depends on the knowledge of human resources and the promotion of programs on using them more efficiently. To this end, they should be specified and analysed independently and in correlation, factors that determine the quality of the human factor: the physical and mental characteristics of performers, origin, behaviour, career aspirations, interests, perspective, adaptability, work speed, stability, fluctuation, creativity, labour protection and safety, working conditions, time effort, job satisfaction, level of earnings, labour relations and social etc. Of course, depending on the quality of the physical, mental, and professional conduct and assessing the nature and conditions of work performer, human ability to work is variable; the trend of all concerns in this area being the increase in its contribution so that the quantity determined by work, to obtain maximum results. In this context, labour productivity growth requires new labour relations in all activity fields, for each member of the work team or increasing individual and collective responsibility, strict compliance with order and discipline, exemplary performance of duty, as required by the Labour Code.

Rational use of labour is both an indispensable condition of fully, superior capitalization, to all factors of production, and a result of this process. The contribution of the human factor in economic development reflects a complex process in which equally rational employment, labour utilization and labour productivity social are required. The concept of work capacity in the direction of achieving its maximum potential can never be judged exactly. The human body never spends the maximum of its energy, but saves an important reserve that uses only in extreme cases. The concept of work capacity in its full appearance remains a theoretical concept (Burloiu, 1997). It is a limit that cannot be determined exactly, with some samples, tests by which we can determine whether this limit is above or below. In relation to the work, ability to work may be primarily physical work capacity, work capacity nerve (neuro-sensory) or brain (mental). In practice, the three general types are combined.

\section{Manifestation of labour productivity}

Reflecting the direct or indirect consequences of the effective use of human capital on economic indicators system - financial firm can be represented in the diagram in Figure 1. 


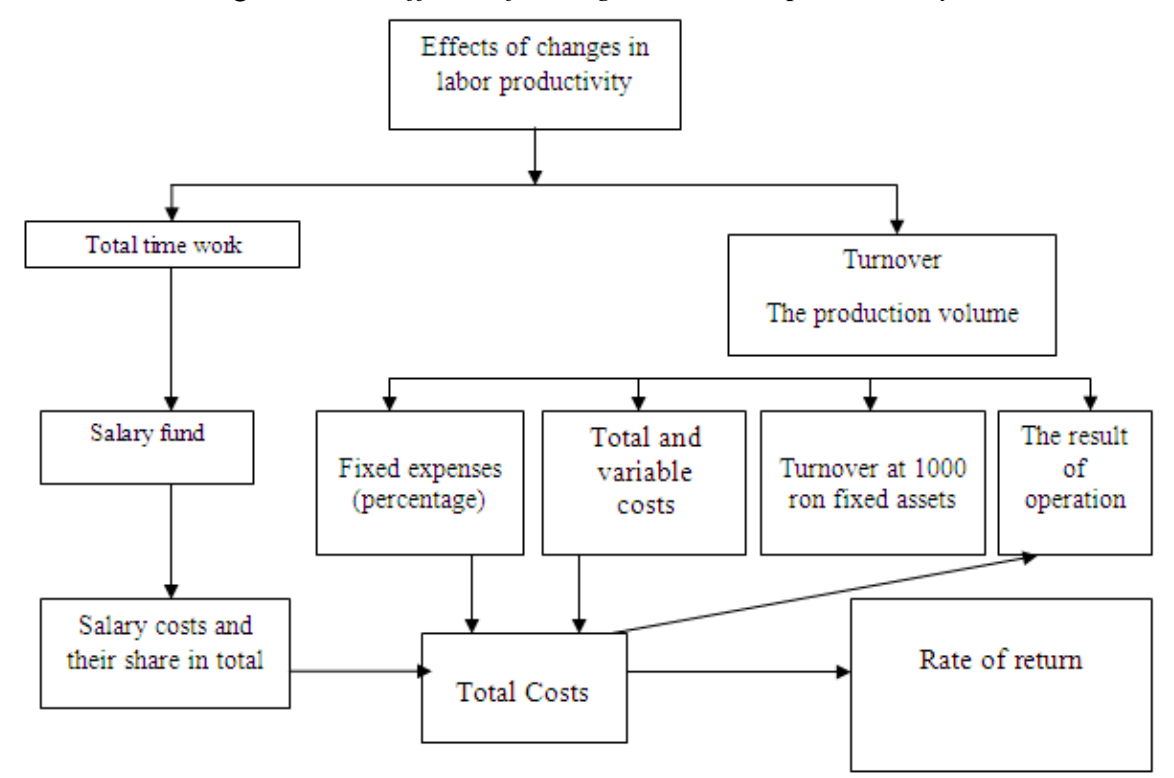

Source: Niculescu, M. Global strategic diagnostic (Bucharest: Publishing House, 1997), p. 114

As shown in the diagram shown, the direct effect of labour productivity growth is reflected in increased turnover and production volume and reducing total labour time, from which the salary increase and the reduction of their share in the total expenditure.

This way of measuring the results highlights:

- Physical productivity which measures efficiencies in nature of using production factors, is being expressed in physical units (natural or naturalconventional);

- Productivity value for measuring the effectiveness of monetary and financial terms. It is widely used in the management of modern enterprises.

- In specialized literature, the productivity is addressed, but, especially on the two dedicated types, namely:

- Overall productivity, which captures the combined effects of all factors of production, measuring performance and efficiency of their overall;

- Partial productivity, of each production factor expressing products obtained through the use of each factor of production consumed.

Size of labour productivity is measured either by the quantity and by quality of goods produced by a unit of work, either by resting expense per unit of economic good. Labour productivity can be determined as an average size and as a marginal productivity. In economic practice, the output is expressed in natural units conventional and value, and labour costs can be expressed in units of time or number of employees, so productivity will be measured in natural units, natural - 
conventional or value. Average productivity and marginal productivity of labour characterized each having a particular relationship between factor 1 and workload. Characterization of work efficiency can be achieved using indices created through the involvement as an effect of the exploitation result or the exercise result.

\section{Conclusions}

The complexity and multiple dimensions of work generated by economic progress, technological, social and cultural approaches led to the multidisciplinary study of the labour process. Thus, to gain a thorough understanding of contemporary issues as labour, it has been analysed both from an economic perspective and sociological, psychological, cultural, political or historical. Through its content and objectives, work standardization can be done only through a permanent collaboration of management and decision makers, of production processes with the help of policy rules workers, closely with designated staff to apply them, collaboration that is recommended to be completed during all stages of the standardization work.

Increasing productivity means reducing systematic manpower costs, reflected on the unit produced, work or service which directly contributes to lower costs and increase efficiency of work performed. Finally, labour productivity growth makes the decisive growth of material production, GDP and accumulations, improves living standards and life of citizens. Size of labour productivity is measured either by the quantity and by quality of goods produced by a unit of work, either by resting expense per unit of economic good.

To improve overall performance, every company must react to changing all aspects of human resources and be aware of their importance. Theoretical research conducted in this paper was part of this logic and contributed to the enrichment of information on labour productivity in a modern organization.

\section{Notes}

[1] According to a study by the National Trade Union Bloc, under the "Office for observing labour market and job quality" referred to http://www. capital.ro/detalii-articole/stiri/bns-productivitatea-muncii-in-romania-aproape-lajumatate-fata-de-mediaeuropeana-143723.html

[2] Adam Smith considered profitable as the first deduction from the product of labour spent on farming and profit representing what it is the second deduction from the product of labour employed in agriculture and the first deduction when work was used in other areas. 


\section{REFERENCES}

1. Angelescu, C. (2000), Resursele umane în pragul secolului XXI, Bucureşti: Editura Economică, p. 301-303.

2. Burloiu, P. (1997), Managementul resurselor umane - Tratare globală interdisciplinară, Bucureşti: Lumina Lex, p. 233.

3. Giarini, O. and Liedtke, P. (2001), Dilema ocupării forţei de muncă şi viitorul muncii - Raport către Clubul de la Roma, Bucureşti: All Beck, p. 30.

4. Gide, Ch. and Rist, Ch. (1926), Istoria doctrinelor economice, Bucureşti: Editura Casei Şcoalelor.

5. Manolescu, A. (2001), Managementul resurselor umane, Bucureşti: Economică.

6. Niculescu, M. (1997), Diagnostic global strategic, Bucureşti: Economică.

7. Osoian, C., and Zaharie, M. (2008), Managementul muncii, Cluj Napoca: Editura Casa cărţii de Ştiinţă.

8. Platis, M. (2000), Capitalul uman - o investiţie profitabilăa?, București: Editura Economică.

9. Purdea, D. (1994), Ergonomie şi studiul muncii, Cluj-Napoca: Daco-Press.

10. Radu, P. (2004), Potenţialul uman al firmei - Asigurare si utilizare, Iaşi: Polirom.

11. Smith, A. (1992), Avuţia Naţiunilor, Chişinău: Editura Universitas.

12. Say J.B. (1803), Traite d'Economie politique, ou simple Exposition de la manière dont se forment, se distribuent et se consomment les richesses, Paris.

13. http://www.capital.ro, accesed in 07.01.2014 
